\title{
Semi-viviparous embryo development and dehydrin expression in the mangrove Rhizophora mucronata Lam.
}

\author{
Flora AbdulRahman Ismail • Lisette M. C. Nitsch • \\ Mieke M. C. Wolters-Arts • Celestina Mariani • \\ Jan W. M. Derksen
}

Received: 23 July 2009/Accepted: 8 December 2009/Published online: 19 January 2010

(C) The Author(s) 2010. This article is published with open access at Springerlink.com

\begin{abstract}
Rhizophora mucronata Lam. is a tropical mangrove with semi-viviparous (cotyledon body protrusion before shedding), non-quiescent and non-desiccating (recalcitrant) seeds. As recalcitrance has been thought to relate to the absence of desiccation-related proteins such as dehydrins, we for the first time systematically described and classified embryogenesis in $R$. mucronata and assessed the presence of dehydrin-like proteins. Embryogenesis largely follows the classic pattern till stage eight, the torpedo stage, with the formation of a cotyledonary body. Ovule and embryo express radical adaptations to semi-vivipary in the saline environment: (1) A large, highly vacuolated and persistent endosperm without noticeable food reserves that envelopes the developing embryo. (2) Absence of vascular tissue connections between embryo and maternal tissue, but, instead, transfer layers in between endosperm and integument and endosperm and embryo. Dehydrin-like proteins $(55-65 \mathrm{kDa})$ were detected by the
\end{abstract}

Communicated by Anna Koltunow.

F. A. Ismail - L. M. C. Nitsch - M. M. C. Wolters-Arts

C. Mariani $(\bowtie) \cdot J$. W. M. Derksen

Department of Plant Cell Biology, IWWR, RU Nijmegen,

Heyendaalseweg 135, 6525 AJ Nijmegen, Netherlands

e-mail: c.mariani@science.ru.nl

L. M. C. Nitsch

e-mail: lisette.nitsch@wur.nl

F. A. Ismail

Department of Botany, University of Dar es Salam,

P.O. Box 35060, Dar es Salam, Tanzania

Present Address:

L. M. C. Nitsch

Department of Biochemistry, Wageningen University,

Dreijenlaan 3, 6703 HA Wageningen, Netherlands
Western analysis, in the ovules till stage 10 when the integuments are dehisced. An additional $50 \mathrm{kDa}$ band was detected at stages $6-8$. Together these results suggest a continuous flow of water with nutrients from the integument via the endosperm to the embryo, circumventing the vascular route and probably suppressing the initially induced dehydrin expression.

Keywords Dehydrins - Embryo development . Mangroves $\cdot$ Rhizophora mucronata $\cdot$ Semi-vivipary

\section{Introduction}

Most angiosperms disperse their seeds in a dormant, dry and resting, condition, so called orthodox seeds. In contrast, viviparous plants develop embryos that do not enter dormancy nor desiccate and germinate whilst attached to the maternal plant. Members of the Rhizophoraceae show continuing embryo growth prior to dispersal, albeit not vivipary in sensu stricto. Instead, they develop a cotyledon body that protrudes from the seed, with the radicle germinating and protruding only after shedding. We characterize this process as "semi-vivipary" in this work. The semi-viviparous seed, which remains attached to the mother plant, is termed a "propagule". Embryos of such species either omit or modify a number of post-fertilization events. In angiosperms, this behaviour is restricted to some mangroves and members of the sea grass genera Amphibolis and Thalassodendron (Elmqvist and Cox 1996). Mangroves are woody species found in brackish or saline tropical and subtropical tidal areas. Representative genera of semi- or true-viviparous mangroves include Rhizophora, Bruguiera, Ceriops and Kandelia of the tribe Rhizophoreae, family Rhizophoraceae (Tomlinson 2000). 
In orthodox seeds, quiescence is acquired during the later stages of maturation, at the same time that a considerable quantity of water $(\sim 90 \%)$ is gradually lost by desiccation (Finkelstein et al. 2002). Desiccation tolerance acquisition is marked by a variety of factors such as an increase in low molecular weight solutes and the appearance of dehydrins, the D11 family (Dure 1993a, 1993b) of late embryogenesis abundant (LEA) proteins (Battaglia et al. 2008; Close 1997; Finkelstein et al. 2002; Ingram and Bartels 1996; Wise and Tunnacliffe 2004). Dehydrins are detected in several tissues during stress and development. They are suggested to be involved in resisting environmental stresses by stabilizing proteins and membrane structures at low water conditions (Allugulova et al. 2003; Arora et al. 1997; Campbell and Close 1997; Ingram and Bartels 1996; Rorat 2006; Wise and Tunnacliffe 2004). Dehydrins are in general thermostable, hydrophilic and contain at their carboxy-terminus a "K-motif", which in angiosperms includes the amino acid residue consensus sequence, EKKGIMDKIKEKLPG (Close 1996).

Absence of dehydrins in mature mangroves seeds has been related to vivipary (Farrant et al. 1996); however, there are no reports on their expression during embryogenesis. Presently, we systematically described and staged embryo development in Rhizophora mucronata and assessed the presence of dehydrins in ovules and embryos through development from fertilization to the point of emergence from the micropyle.

\section{Materials and methods}

\section{Plant material}

Flowers and ovaries from $R$. mucronata Lam. were collected during February-March from Mbweni fishing village, $40 \mathrm{~km}$ from Dar es Salaam, Tanzania. In $R$. mucronata, several stages of development (from flower bud to propagule) can often be found on a single plant. The trees grow almost exclusively in single stands, and samples were collected from $\sim 25$ trees at a single site to ensure that developmental stages were representative of the local population. Synchrony of each developmental stage is at best an estimate, since the sample population is wild and the environment unsettled.

\section{Chemicals}

Unless stated otherwise, all chemicals (P.A. grade.) were from Merck (Darmstadt, Germany). The polyclonal anti-dehydrin anti-serum and peptide-salt containing the dehydrin K-segment consensus peptide were kind gifts from Dr T. Close (Riverside, CA, USA).
Light microscopy

All materials were prepared according to standard techniques. Ovules were immediately dissected with much of the testa removed before fixation using $2 \%$ glutaraldehyde and $1 \%$ paraformaldehyde in buffer (100 mM PIPES pH 7.0, 2\% sucrose, $0.05 \% \mathrm{CaCl}_{2} \cdot 2 \mathrm{H}_{2} \mathrm{O}$, and $0.1 \%$ Tween 20 ). The samples were infiltrated with Paraplast via a water-ethanolxylene series. Sections (5-7 $\mu \mathrm{m}$ thick) were cut using an AO 820 microtome (American Optical, Ramsey, MN, USA), were de-paraffinated, rehydrated and stained with $0.1 \%$ toluidine blue $\mathrm{O}$ in borate buffer ( $\mathrm{pH}$ 8). In addition, 1- $\mu \mathrm{m}$ thick sections were made using Spurr's resin-embedded material (see below) and stained with $1 \%$ aqueous toluidine blue. Micrographs were made using a Leitz Orthoplan microscope (Leica Microsystems GmbH, Wetzlar, Germany) equipped with a Coolsnap digital camera (Roper Scientific, Tucson, AZ) and Meta Vue (Universal Imaging Corporation, West Chester, PA, USA) imaging software.

\section{Electron microscopy}

Aldehyde-fixed ovules were post-fixed in $2 \% \quad \mathrm{OsO}_{4}$ in double distilled water, dehydrated in a water-ethanol series and embedded in Spurr's resin (Polysciences Inc., Warrington PA, USA; Spurr 1969). Ultrathin sections $\sim 90 \mathrm{~nm}$ thick were made using a Sorvall MT-5000 ultramicrotome (Analytical Instruments LLC, Golden Valley, MN, USA) and glass knives, with sections mounted on Formvarcoated copper grids. Sections were stained with $2 \%$ uranyl acetate for $20 \mathrm{~min}$ and lead citrate for $5 \mathrm{~min}$ according to Reynolds (1963). Examination and photographing occurred with a JEOL 100CX II transmission electron microscope operated at $60 \mathrm{kV}$.

\section{Protein extraction}

Proteins were extracted from freeze-dried ovules/seeds at different stages of development (Table 1) using the procedure of Farrant et al. (1996) for recalcitrant seeds. The extraction buffer was made up of $50 \mathrm{mM}$ Tris- $\mathrm{HCl}(\mathrm{pH}$ 7.0), $0.7 \mathrm{M}$ sucrose, $50 \mathrm{mM}$ EDTA, $0.1 \mathrm{M} \mathrm{KCl}, 2 \mathrm{mM}$ PMSF (phenylmethylsulphonyl fluoride) and $2 \%$ $\beta$-mercaptoethanol. The samples were ground with extraction buffer $(1 \mathrm{ml}: 10 \mathrm{mg})$, agitated on ice for $30 \mathrm{~min}$ and then centrifuged at $16,000 \times g$ at $4{ }^{\circ} \mathrm{C}$ for $10 \mathrm{~min}$. One additional extraction of the pellet was done. Supernatants were precipitated with $0.1 \mathrm{M}$ ammonium acetate overnight at $-20^{\circ} \mathrm{C}$. The next day, precipitates were washed with ammonium acetate, dried with acetone and ethanol and resuspended in $\mathrm{PBS}$ at $\mathrm{pH}$ 7.5. Heating of the extracts did not change the detection of dehydrin-like protein bands and was therefore omitted. For protein quantification we used 
Table 1 Morphogenesis staging in $R$. mucronata ovaries from anthesis through propagule maturation

\begin{tabular}{|c|c|c|c|}
\hline Stage & Ovary $\emptyset^{a}$ & Field markers ${ }^{\mathrm{b}}$ & Histology $^{\mathrm{c}}$ \\
\hline 0 & 0.4 or less & $\begin{array}{l}\text { Anthesis: flower open } \\
\text { Calyx: yellow, } 2 \mathrm{~mm} \\
\text { Corolla: white, } 3 \mathrm{~mm} \\
\text { Stamens: present, beige } \\
\text { Ovary: yellow } \\
\text { Ovules: four, translucent pale green }\end{array}$ & Degeneration of nucellus \\
\hline 1 & $0.4-0.6$ & $\begin{array}{l}\text { Anthers and corolla detached } \\
\text { Calyx: yellow } \\
\text { Ovules: four, translucent pale green }\end{array}$ & Fertilization \\
\hline 2 & $0.6-0.7$ & $\begin{array}{l}\text { Calyx extension by ovary growth } \\
\text { Ovules pale yellow, opaque } \\
\text { Unfertilized ovules smaller than fertilized ones }\end{array}$ & $\begin{array}{l}\text { Early embryogenesis, few-celled globular embryo } \\
\text { Cellular endosperm. Compressed cells with thickened walls } \\
\text { surround the embryo } \\
\text { Start of suspensor formation at the micropylar side }\end{array}$ \\
\hline 3 & $0.8-1.0$ & $\begin{array}{l}\text { Calyx drawn flat (approx. } 180^{\circ} \text { ) } \\
\text { Ovule colour light peach opaque } \\
\text { Unfertilized ovules smaller than fertilized ones and brown }\end{array}$ & $\begin{array}{l}\text { Embryo at globular stage } \\
\text { Compressed cells with thickened walls differentiate into } \\
\text { transfer cells } \\
\text { Development of the transfer cell layer in the integument }\end{array}$ \\
\hline 4 & $1.0-1.2$ & $\begin{array}{l}\text { Calyx pushed out further, bending towards petiole } \\
\text { Calyx colour: green } \\
\text { Ovary colour: yellow-green } \\
\text { Ovule's micropylar end open with endosperm visible }\end{array}$ & $\begin{array}{l}\text { Embryo polarization with cell divisions in the distal region } \\
\text { (away from micropyle). } \\
\text { Endosperm with transfer layer surrounding suspensor and } \\
\text { embryo } \\
\text { Fully developed transfer cell layer in the integument }\end{array}$ \\
\hline 5 & $1.2-1.4$ & $\begin{array}{l}\text { Ovule expansion in proximal region } \\
\text { Endosperm visible outside micropyle area }\end{array}$ & $\begin{array}{l}\text { Embryo club shaped. Distal region with relatively small and } \\
\text { rapidly differentiating cells } \\
\text { Multiseriate suspensor and surrounding transfer cells in } \\
\text { endosperm fully developed }\end{array}$ \\
\hline 6 & $1.4-1.6$ & $\begin{array}{l}\text { Ovary longer than wide } \\
\text { Ovary colour: green } \\
\text { Endosperm clearly protruding from micropyle }\end{array}$ & $\begin{array}{l}\text { Embryo becoming heart-shaped and developing into a torpedo } \\
\text { shaped embryo } \\
\text { Meristem initiation; site marking future root meristem evident } \\
\text { at proximal side }\end{array}$ \\
\hline 7 & $1.6-1.8$ & Ovary wall darkening in proximal region close to petiole & $\begin{array}{l}\text { Embryo attains a torpedo shape and emerges from the } \\
\text { micropyle } \\
\text { Root and shoot meristem present }\end{array}$ \\
\hline 8 & $1.8-1.9$ & $\begin{array}{l}\text { Hypocotyl obvious outside micropyle } \\
\text { Calyx completely bent towards petiole }\end{array}$ & $\begin{array}{l}\text { Development of the cotyledonary body } \\
\text { Hypocotyl growth through endosperm } \\
\text { Suspensor degenerates }\end{array}$ \\
\hline 9 & $1.9-2.0$ & $\begin{array}{l}\text { Ovary colour: dark and with brown spots } \\
\text { Hypocotyls emerged from ovary wall but remain attached to } \\
\text { ovary and maternal plant }\end{array}$ & $\begin{array}{l}\text { Fully developed embryo with fused cotyledons pushed out by } \\
\text { the endosperm } \\
\text { Drying and degeneration of integuments }\end{array}$ \\
\hline 10 & 2.0 & Large green propagules gradually extending & Growth outside ovary \\
\hline
\end{tabular}

${ }^{a}$ Ovary size classes from field measurements expressed in $\mathrm{mm}$

b Field indicators for stage identification

c Taken from light microscopic images of endosperm and embryo sections (see also: Juncosa 1982)

the SDS-compatible staining protocol from DieckmannSchuppert and Schnittler (1997).

Western blot analysis

Approximately $1.5 \mu \mathrm{g}$ total protein was separated using SDS-PAGE. Pairs of loaded gels of $12.5 \%$ were run at
$100 \mathrm{~V}$ for $2 \mathrm{~h}$. One gel was electro-blotted onto a $0.45-\mu \mathrm{m}$ pore size nitro-cellulose membrane (Optitran BA-S 85, Whatman-Schleicher \& Schuell GmbH, Dassel, Germany) and dried between two Whatman filter papers for Western blot analysis. As a negative control, $5 \mu \mathrm{mol}$ tobacco lipid transfer protein (LTP; Nieuwland et al. 2004) having none of the dehydrin $\mathrm{K}$-segment sequence was spotted on the 
blot. The counter gel was stained with Coomassie brilliant blue $(\mathrm{CBB})$ for confirmation of protein loading. Blots for Western analysis were washed twice with TBS ( $\mathrm{pH} 7.5)$. Non-specific binding was blocked with $10 \%$ skimmed milk powder in TBS overnight. The primary antibody (Close et al. 1993) directed to the K-segment consensus peptide was 1:1000 diluted in TBS with 5\% skimmed milk powder. Incubation was conducted overnight at $4{ }^{\circ} \mathrm{C}$. Then, the blots were washed three times for $5 \mathrm{~min}$ in TBST (TBS with $0.1 \%$ Tween-20) and incubated with the secondary antibody, an anti-rabbit immunoglobulin $\mathrm{G}$ conjugate with horseradish peroxidase (Sigma-Aldrich, Zwijndrecht, The Netherlands) diluted 1:20,000 with TBS with 5\% skimmed milk powder for $60 \mathrm{~min}$. Finally, blots were washed thrice for $5 \mathrm{~min}$ with TBST. As a control, anti-dehydrin serum blocked with the consensus peptide was used. Proteins were detected using a West Pico Chemiluminescence kit (Pierce, Rockford, IL, USA), according to the manufacturer's recommendations. The film was developed using a CEAPRO processing machine (CEA GmbH, Hamburg, Germany). The Western analysis was repeated three times and a representative gel is shown.

\section{Results}

\section{Morphological characterization}

The $\sim 2$-mm long flowers of $R$. mucronata Lam. (Fig. 1) are hypogynous. The ovary consists of two carpels. Starting at anthesis, the following field parameters were used to arbitrarily stage further development: (1) Presence and colour of flower parts, i.e., calyx, corolla and stamen. (2)

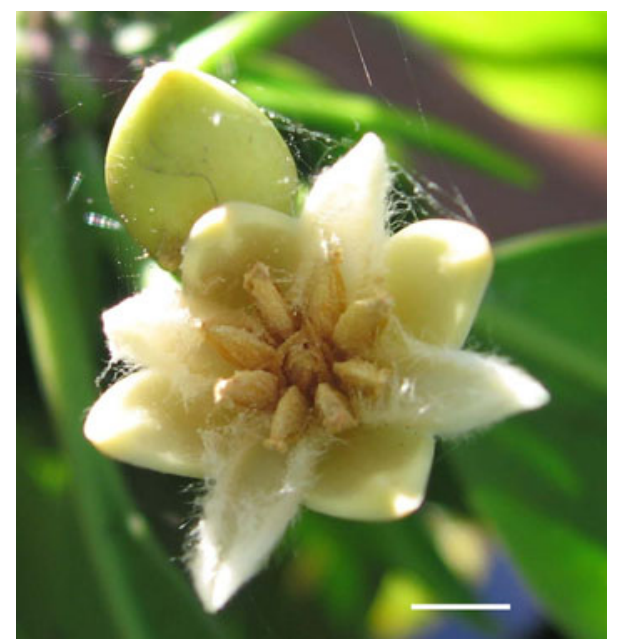

Fig. 1 Flower of $R$. mucronata with four cream-coloured hypogyne sepals and petals. The sepals are broad and smooth, petals acute with villous margins. The eight anthers are yellow, the ovary is light brown. Bar $1 \mathrm{~mm}$ (colour figure online)
Ovary size and colour. (3) Presence, colour and size of ovules. (4) Visibility of endosperm development. (5) Hypocotyl emergence. The null stage was identified as a recently opened flower with corolla and stamens still attached. A schematic representation of the successive stages together with the major histological events is presented in Table 1 and Fig. 2. The duration of the different stages was variable, but stage 9 was always completed within 13 weeks after anthesis.

\section{Megagametogenesis}

Microscopic examination of $R$. mucronata ovaries at anthesis (stage 0) showed two locules with two ovules each. Only one of the four ovules will ultimately develop into a propagule. At stage 0 (Fig. 3a, b), a bitegmic ovule with the embryo sac surrounded by the remnants of a largely degenerated nucellus was clearly recognized. These in turn are enclosed by the inner integument, except at the micropylar region (Fig. 3b, c), where the pollen tubes penetrate the inner integument to reach the embryo sac (Fig. 3c). Some of the embryo sacs appear to have collapsed by this stage, and their ovules degenerate soon afterwards. The distinction between inner and outer integuments is no longer evident at middle stages of embryo development. Integumentary cells appear to remain viable in developing ovules.

\section{Embryogenesis}

Only a single fertilized embryo sac develops; all others rapidly degenerate. The loose attachment of the embryo sac to the integuments greatly facilitates microscopic preparation of the early stages (Fig. 3d), but may have led to embryo loss during sectioning and/or fixation. In addition to asynchronous ovule development (Juncosa 1982b), ovule loss may also contribute to the poor understanding of early embryo stages and the sparse documentation of early fertilization stages in this species. Stage 1, anthesis till fertilization, was completed within 7 days, its duration depending on the time of fertilization after anthesis.

During embryogenesis, the endosperm rapidly proliferated, fully surrounding the embryo at stage 2 and separating the embryo from the integument and the micropyle (Fig. 3d). No vascular connections with the maternal tissue were present. The expansion of the endosperm forces the micropyle to open at stage 4 , leading to the emergence of the embryo from the micropyle at stage 6 (Fig. 2j). Large flattened cells surround the embryo in stage 2 (Fig. 3d). They develop into the typical layer of labyrinthine transfer cells seen at stage 5 (Fig. 3e, f, inset). With further outgrowth of the embryo, the transfer cells appear to lag during the later development until they degenerate together 

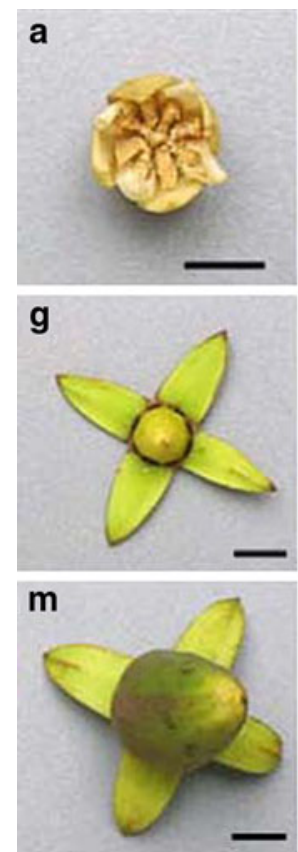
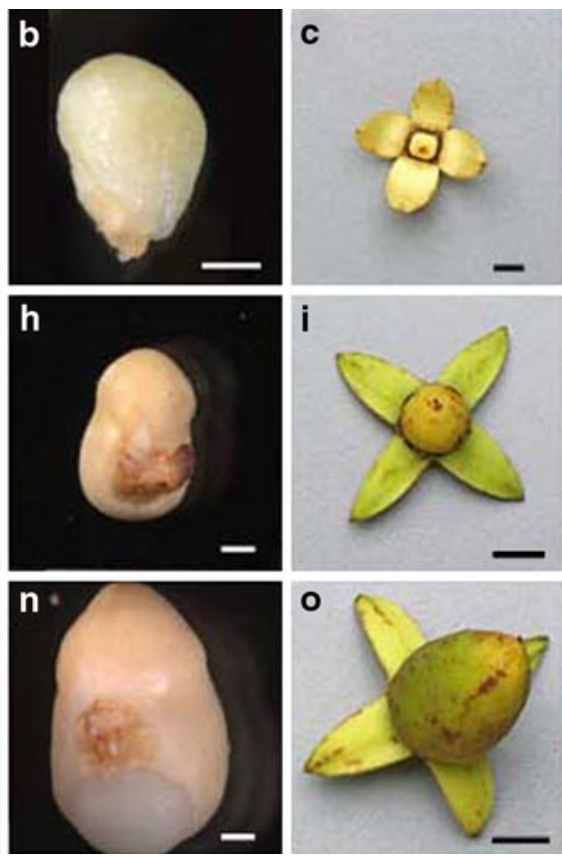
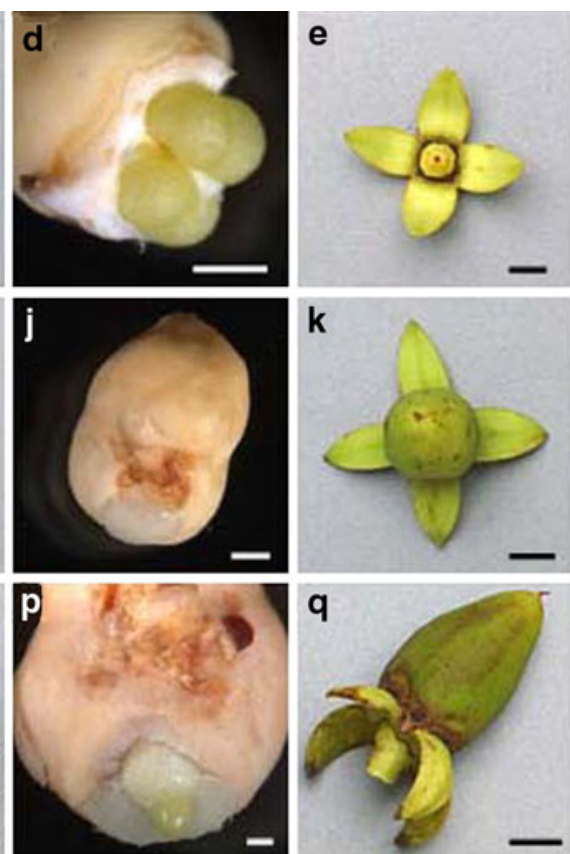
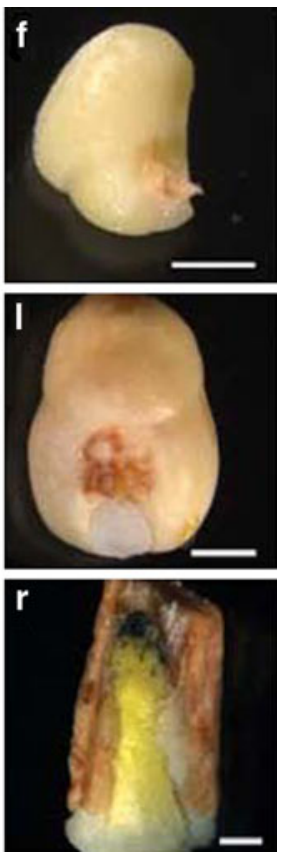

Fig. 2 R. mucronata developmental stages, as described in Table 1. Grey panels show external flower and ovary changes for stages 1-9, with the corresponding external morphology of the ovules shown in black panels. In all images, the micropylar end faces downward. Bars 2 mm

with the suspensor at stage 8 . Another layer of transfer cells with thick labyrinthine walls surrounding the endosperm was visible at stage 4 (not shown). This stage was completed within 6 weeks. From the first observations on stage 2, the endosperm appeared cellular and highly vacuolated with scant cytoplasm. Only in the outer endosperm cell layer and in the flattened transfer cells around the embryo (Fig. 3d, e) was denser cytoplasm seen. No indications for the presence of endosperm storage in the form of amyloplasts, lipid globules or protein bodies could be inferred from the light and EM observations.

Rhizophora mucronata embryos have a multiseriate suspensor which is first evident at stage 2 (Fig. 3d) and reaches its full development at stage 5 , persisting until the emergence of the cotyledon body from the micropyle at stages 7-8 (Fig. 2i). The suspensor points towards the micropyle. At stage 8, the suspensor starts to degenerate. Suspensor cells are relatively large when compared to those of the embryo proper, with distinct globular organelles. As these organelles are not osmiophilic and stain densely with Fast Green FCF (data not shown), they probably represent protein bodies.

The zygote of $R$. mucronata undergoes a series of cellular divisions that result in a globular embryo proper and a suspensor. The division pattern in development does not seem very strict and therefore cannot be attributed to a specific pattern of embryo development (see also Juncosa 1982a). At stage 2, the embryo is clearly globular, and events in embryogenesis such as differentiation of the suspensor became evident (Fig. 3d). By stage 4 (Fig. 3e), the embryo is highly polarized with larger, more highly vacuolated cells in the embryo proper and more amyloplastcontaining cells at the suspensor pole. As a result of cell divisions in the chalazal region (opposite the micropyle), the embryo progressively changes its shape into a club during stages 4 and 5. A fully developed transfer cell layer of endosperm surrounds the club-shaped embryo at stage 5 (Fig. 3f). At stage 6, divisions in localized regions of the club-shaped embryo (Fig. 3g) indicate the sites where the meristems will form. Two sites at the outermost layer of the distal region mark the future cotyledons. As cotyledons develop, the region between them marks the site of future shoot meristem formation. Simultaneously, at the centre of the pro-embryo, another region of rapidly dividing cells becomes evident that will form the future apical root meristem. With further divisions, the shape of the embryo is altered from that of a club to that of a heart. This stage is generally reached within 9 weeks. Further cell divisions at stages 6 and 7 give rise to the typical form of the Rhizophoraeceae embryo, which forms a typical toroidal cotyledonary body (Fig. 3h) with elongating cotyledons at the beginning of stage 8 (Fig. 3i). During stage 8 , the cotyledonary body and hypocotyl develop, and the embryo is pushed out by the endosperm. Stage 8 is completed within 11 weeks. At the end of stage 9, the cotyledons are fused and the embryo emerges. The seed remains attached to the ovary via the hypocotyl. As the integuments degenerate and dry, the large green propagule becomes visible at stage 10 . 


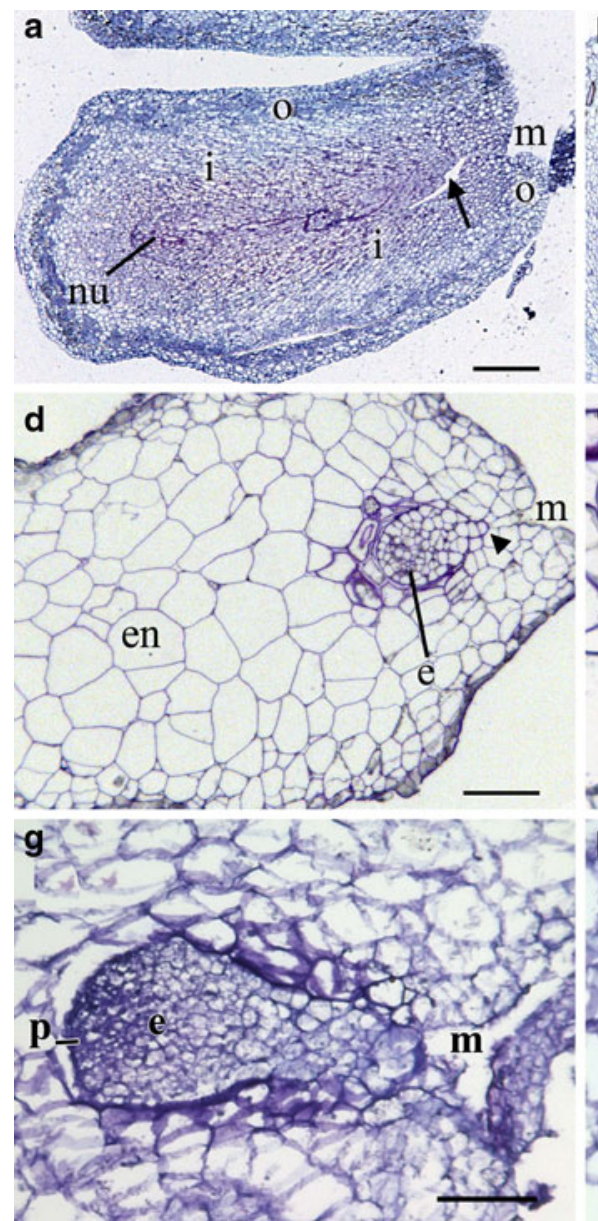

Fig. 3 Light microscopic images from toluidine blue stained sections of developmental stages $0-8$ of $R$. mucronata embryogenesis. Unless otherwise indicated, all sections were made at the near median longitudinal plane. a Ovule at stage 0 showing inner $(i)$ and outer $(o)$ integument, nucellus $(\mathrm{nu})$ and micropyle $(\mathrm{m})$ with micropylar canal (arrow). The embryo sac apparently has collapsed. b Similar image as in a showing a large embryo sac (es) with egg apparatus (ea) at the micropylar pole. The nucellus $(n u)$ is laterally displaced and inconspicuous. c At stage 1, two synergids $(s)$ with filiform apparatus (*) and egg nucleus (arrow) are clearly visible. Remnants of the nucellus $(n u)$ remain around the egg apparatus, with an apparent pollen tube (unlabelled arrowheads) located in the nucellus $(n u)$. d Endosperm (en) with globular embryo (e) prepared from a stage 2 ovule. At the micropylar end $(m)$, the beginning of the suspensor (unlabelled arrowhead) can be seen. Endosperm cells around the embryo have a thick-walled and compressed appearance, whereas the

\section{Protein analysis}

Western blot analysis indicates protein bands with affinity to the $\mathrm{K}$ dehydrin motif between 55 and $65 \mathrm{kDa}$ in ovules and seeds at all stages of development (Fig. 4). An additional band at approximately $50 \mathrm{kDa}$ was consistently observed in stages 6-8. In stage 9, when the embryo emerges from the micropyle, the $65 \mathrm{kDa}$ band remains evident and the 50 and $55 \mathrm{kDa}$ bands become variable and less obvious. The 65 and $55 \mathrm{kDa}$ bands were also found in outermost endosperm cells appear to remain small with dense cytoplasm. e Embryo (e) at stage 4 shows the relatively large cell cells of the suspensor (unlabelled arrowhead) towards the micropyle. Suspensor cells contain less cytoplasm but more amyloplasts than cells in the embryo proper. Large transfer-like cells $(t)$ with denser cytoplasm surround the embryo. f Near cross-section of the ovule at stage 5. Transfer cells $(t)$ with thick walls $\left({ }^{\wedge}\right)$ surround the embryo $(e)$. TEM image (inset) clearly shows the labyrinthine character of the thick transfer cell walls. g At stage 6, the embryo is club-shaped with relatively small cells forming at the proximal side $(p)$. h Oblique section through a heart-shaped embryo $(e)$ at stage 7 showing toroidal primordium (white dots) that will form the cotyledonary body; unlabelled arrowhead depicts suspensor pole. i At stage 8, cotyledons (c) are well developed; shoot (arrow) and root (pointer) apical meristems can be recognized. Suspensor is still visible (upper left). a, b, i: Bars $200 \mu \mathrm{m} ; \mathbf{d}, \mathbf{g}, \mathbf{h}$ : Bars $100 \mu \mathrm{m} ; \mathbf{c}, \mathbf{e}, \mathbf{f}$ : Bars $50 \mu \mathrm{m}$

leaf tissue, together with an additional prominent band at $34 \mathrm{kDa}$. Protein integrity was confirmed by Coomassie Brilliant Blue staining (not shown).

\section{Discussion}

The abscission of corolla and stamens at fertilization formed a clear and reliable mark for the onset of embryogenesis. Ovary size was used to further characterize 


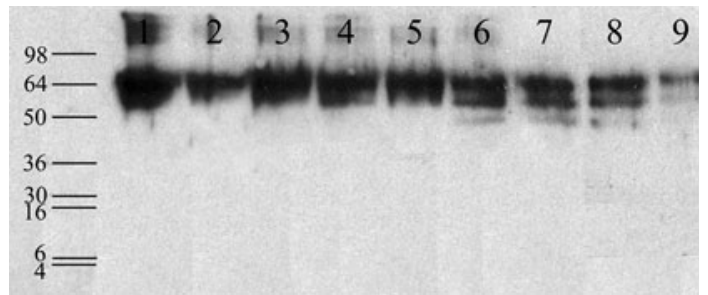

Fig. 4 Western blot indicates protein bands with affinity to the $\mathrm{K}$ dehydrin motif in ovules and seeds at all stages of development. Lanes 1-9 indicate corresponding stages of development (Table 1). Dehydrin-like proteins of $50-65 \mathrm{kDa}$ are present throughout development

the stage of ovule and embryo development, though in addition, colour of ovary and calyx and calyx position could be used in later stages (Fig. 2, Table 1). Ovary and embryo development were largely similar to that described by Juncosa (1982a, b) for Rhizophora mangle, but differences were observed especially in the younger stages of embryo development. Due to the wild background of the population and varying environmental conditions, the time course of embryogenesis appeared variable. In contrast to the observations for $R$. mangle by Juncosa (1982b), the loss of the inner integument was not seen in $R$. mucronata, although visible distinction between inner and outer integument (Fig. 3a, b) was lost during the first stages of embryo development. Though fertilization could be observed (Fig. 3c), the first cell divisions at stage 1 were not observed in both this and previous studies (Juncosa 1982b; Tomlinson 2000) on the Rhizophoraceae. Apparently they pass quickly, without a significant reflection in ovary or flower development. The observations on early embryogenesis were hampered by the small size of embryo and endosperm in the large and fibrous ovule. The collapse of the embryo sac in some ovules and osmotic damage during preparation further complicated analysis.

Interestingly, the suspensor appeared to remain completely surrounded by endosperm without contacting the integument (Fig. 3d). Separation of the suspensor from the integument and an embryo enveloped by endosperm may not be unique for Rhizophoraceae, as Treub (1883) noted that in Avicennia (Avicenniaceae), the young embryo was embedded in the endosperm mass protruding from the micropyle. The layer of transfer cells at the inner surface of the integument surrounding the endosperm (stage 4) and the vacuolated, persistent endosperm in Rhizphora (Juncosa 1982a, b; Wise and Juncosa 1989) is not found in other taxa, be they non-related mangroves or related nonmangroves. Presumably, the transfer cell layer is functionally similar to the extensive endosperm haustoria seen in Avicennia marina (Avicenniaceae) (Farrant et al. 1992), but represents an independent development within the Rhizophoraceae.
The typical layer of the labyrinthine transfer cells surrounding the embryo seen at stage 5 (Fig. 3e, f, inset) appear to degenerate together with the suspensor at stage 8 . Due to its transient character, this transfer layer may easily escape the attention. This particular layer of transfer cells may represent a unique development for $R$. mucronata, as no such layer was recorded in R. mangle (Juncosa 1982b; Wise and Juncosa 1989). As discussed by Wise and Juncosa (1989), transfer cells at the border of suspensor and embryo do occur in many species, though they may have different origins, as for example in Medicago (Sangduen et al. 1983) where they originate from the suspensor. The presence of transfer cell layers between the embryo and the endosperm, whilst vascular connections are absent, shows the emergence of an alternative transport route for water and solutes via the endosperm to the embryo that does not conform to the regular vascular route. Absence of vascular connections, along with the development of two transfer layers associated with the vacuolated endosperm, suggests that a continuous flow of water with nutrients may flow from the integument through the endosperm to the embryo, which would facilitate semi-vivipary. A storage function for the endosperm is then obsolete. The presence of protein bodies in the suspensor cells at stage 7 may indicate their dysfunctional character as protein and lipid bodies are also known to accumulate in the suspensors of defect Arabidopsis embryos (Schwartz et al. 1994).

\section{Dehydrins}

Using an anti-serum for the K-motif of dehydrins, proteins with a molecular weight of between 50 and $65 \mathrm{kDa}$ were detected in both leaves (not shown) and ovules (Fig. 4). Because we did not confirm their true dehydrin character by cDNA or functional analysis, the proteins are referred to as dehydrin-like (Close et al. 1993). The proteins detected here were considered dehydrin-like, based on the immunological affinity with the typical K-motif, which serves as a marker for dehydrins (Close 1997). As the embryos do not undergo dormancy typical of other angiosperms, a possible role for their presence in ovules might include osmotic protection from infiltrating salt, adding to other observed salt stress adaptations in the form of well developed transfer tissues and absence of direct vascular tissue connection with the mother plant (Wise and Juncosa 1989).

Absence of dehydrin-like proteins is not a general feature of recalcitrant seeds, as their absence has been reported to occur in recalcitrant seeds of a number of species from temperate climates and in tropical species, i.e. Castanospermum australe, when growing in temperate climates (Farrant et al. 1996). They have, however, been reported absent in species from tropical wetlands, including mangroves from the genera Avicennia, Bruguiera and 
Rhizophora and some other species (Farrant et al. 1996; Han et al. 1997; Kermode 1997). Recently, Panza et al. (2007) showed the presence of dehydrins in the extremely recalcitrant seeds of the tropical palm tree Euterpe edulis. Our observation of dehydrin-like proteins during seed development in Rhizophora mucronata suggests that they may also be present in some other tropical species that lack seed dormancy.

With maturation at stage 9 , some dehydrin-like proteins seem to disappear. However, the $65 \mathrm{kDa}$ band remained and was also present in leaves, suggesting that this dehydrin-like protein was not developmentally regulated but more generally expressed, e.g., as an adaptation to salt stress. In conventional (orthodox) embryos, dehydrin expression may already be initiated at the heart stage (e.g., Zimmerman 1993; Lin et al. 1996; Sankara Rao 1996), but does not cease as the embryo grows and finally becomes desiccated. The early presence of dehydrin-like proteins well before desiccation suggests that they may also play additional roles. The appearance of the $50-\mathrm{kDa}$ protein in R.mucronata ovules coincides with the heart-shaped embryo (stage 6) and may mark the onset of a conventional developmental programme, which may become suppressed with the onset of semi-vivipary.

In conclusion, $R$. mucronata embryogenesis shows a series of developments that express a radical adaptation to an extreme form of recalcitrance, to which also the disappearance of especially the $50-\mathrm{kDa}$ dehydrin-like protein might be attributed.

Acknowledgments This study was carried out within the Nuffic MHO-ENVIRONS programme. We are greatly indebted to $\mathrm{Dr} \mathrm{T}$. Close (Riverside, California) for his generous gift of the anti-dehydrin anti-serum and peptide-salt containing the dehydrin K-segment consensus peptide. We also thank Dr M. Muruke (University of Dar es Salam) for his continuous support and suggestions, Dr D. Bartels (Rheinische Friedrich-Wilhelms Universtät, Bonn) and Dr K. Weterings (Bayer Bioscience N. V., Belgium) for their interest in this study, and Dr E. S. Pierson (Instrumentation Dept, IWWR, Nijmegen) for help with microscopy.

Open Access This article is distributed under the terms of the Creative Commons Attribution Noncommercial License which permits any noncommercial use, distribution, and reproduction in any medium, provided the original author(s) and source are credited.

\section{References}

Allugulova CR, Gimalov FR, Shakirova FM, Vakhitov VA (2003) The plant dehydrins: structure and putative functions. Biochem (Moscow) 68:945-951

Arora R, Wisniewski ME, Rowland LJ (1997) Low temperatureinduced expression of dehydrins in deciduous fruit crops and their relation to cold acclimation and/or dormancy. Acta Hort 441:175-182
Battaglia M, Olvera-Carillo Y, Garciarubbio A, Campos F, Covarrubias A (2008) The enigmatic LEA proteins and other hydropilins. Plant Physiol 148:6-24

Campbell SA, Close TJ (1997) Dehydrins: genes proteins and associations with phenotypic traits. New Phytol 137:61-74

Close TJ (1996) Dehydrins: emergence of a biochemical role of a family of plant dehydration proteins. Physiol Plantarum 97:795-803

Close TJ (1997) Dehydrins: a commonality in the response of plants to dehydration and low temperature. Physiol Plantarum 100:291-296

Close TJ, Fenton RD, Moonan F (1993) A view of plant dehydrins using antibodies specific to the carboxy terminal peptide. Plant Mol Biol 23:279-286

Dieckmann-Schuppert A, Schnittler HJ (1997) A simple assay for quantification of protein in tissue sections, cell cultures, and cell homogenates, and of protein immobilized on solid surfaces. Cell Tissue Res 288:119-126

Dure LI (1993a) A repeating 11-mer amino acid motif and plant desiccation. Plant J 3:363-369

Dure LI (1993b) Plant responses to cellular dehydration during environmental stress. In: Close TJ, Bray EA (eds) Current topics in plant physiology 10. American Society of Plant Physiologists, Rockville, MD, pp 91-103

Elmqvist T, Cox PA (1996) The evolution of vivipary in flowering plants. Oikos 77:3-9

Farrant JM, Pammenter NW, Berjak P (1992) Development of recalcitrant (homoiohydrous) seeds of Avicennia marina: anatomical, ultrastructural and biochemical events associated with development from histodifferentiation to maturation. Ann Bot 70:75-86

Farrant JM, Pammenter NW, Berjak P, Farnsworth EJ, Vertucci CW (1996) Presence of dehydrin-like proteins and levels of abscisic acid in recalcitrant (desiccation sensitive) seeds may be related to habitat. Seed Sci Res 6:175-182

Finkelstein RR, Gampala SS, Rock CD (2002) Abscisic acid signalling in seeds and seedlings. Plant Cell 14(Suppl.):S15-S45

Han B, Hughes BW, Galau GA, Bewley JD, Kermode AR (1997) Changes in late embryogenesis abundant (LEA) messenger RNAs and dehydrin during maturation and premature drying of Ricinus communis L. seeds. Planta 201:27-35

Ingram J, Bartels D (1996) The molecular basis of dehydration tolerance in plants. Annu Rev Plant Physiol Plant Mol Biol 47:373-403

Juncosa AM (1982a) Embryo and seedling development in the Rhizophoraceae. Dissertation, Duke University Durham, NC

Juncosa AM (1982b) Developmental morphology of the embryo and seedling of Rhizophora mangle L. (Rhizophoraceae). Am J Bot 69:1599-1611

Kermode AR (1997) Approaches to elucidate the basis of desiccation tolerance in seeds. Seed Sci Res 7:75-95

Lin X, Hwang GJH, Zimmermann L (1996) Isolation and characterization of a diverse set of genes from carrot somatic embryos. Plant Physiol 112:1365-1374

Nieuwland J, Feron R, Huisman BAH, Fasolino A, Hilbers CW, Derksen J, Mariani C (2004) Lipid transfer proteins enhance cell wall extension in tobacco. Plant Cell 17:2009-2019

Panza V, Distefano AJ, Carjuzaa P, Lainez V, del Vas M, Maldonado $S$ (2007) Detection of dehydrin-like proteins in embryos and endosperm of mature Euterpe edulis seeds. Protoplasma 231:1-5

Reynolds ES (1963) The use of lead citrate at high pH as an electronopaque stain in electron microscopy. J Cell Biol 17:208-212

Rorat T (2006) Plant dehydrins-tissue location, structure and function. Cell Mol Biol Lett 11:536-556

Sangduen N, Kreitner GL, Sörensen EL (1983) Light and electron microscopy of embryo development in perennial and annual Medicago species. Can J Bot 61:837-849 
Sankara Rao K (1996) Embryogenesis in flowering plants: recent approaches and prospects. J Biosci 21:827-841

Schwartz BW, Yeung EC, Meinke DW (1994) Disruption of morphogenesis and transformation of the suspensor in abnormal suspensor mutants of Arabidopsis. Development 120:3235-3245

Spurr AR (1969) A low-viscosity epoxy resin embedding medium for electron microscopy. J Ultrastruct Res 26:31-43

Tomlinson PB (2000) The botany of mangroves. Cambridge University Press, Cambridge, Melbourne, pp 419
Treub M (1883) Notes sur l'embryon, le sac embryonaire et l'ovule Avicennia officinalis. Annales du Jardin Botanique de Buitenzorg 3:79-87

Wise RR, Juncosa AM (1989) Ultrastructure of the transfer tissues during viviparous seedling development in Rhizophora mangle (Rhizophoraceae). Am J Bot 7:1286-1298

Wise MJ, Tunnacliffe A (2004) POPP the question: what do LEA proteins do? Trends Plant Sci 9:13-17

Zimmerman JL (1993) Somatic embryogenesis: a model for early development in higher plants. Plant Cell 5:1411-1423 